\title{
Characterization and antioxidant capacity of anchovy by-product protein films enriched with rosemary and laurel essential oils
}

\section{Biberiye ve defne uçucu yağları ille zenginleştirilmiş hamsi atık protein filmlerin karakterizasyonu ve antioksidan kapasitesi}

\author{
Serpil Tural ${ }^{1}$ • Sadettin Turhan²* Fatih Öz ${ }^{3}$ \\ ${ }^{1}$ Department of Food Engineering, Ondokuz Mayis University, 55139 Samsun, Turkey \\ 2 Department of Food Engineering, Ondokuz Mayis University, 55139 Samsun, Turkey \\ ${ }^{3}$ Department of Food Engineering, Ataturk University, 25240 Erzurum, Turkey
}

D https://orcid.org/0000-0002-9360-3446

D https://orcid.org/0000-0002-3510-4382

iD https://orcid.org/0000-0002-5300-7519

How to cite this paper:

Tural, S., Turhan, S. \& Öz, F., (2020). Characterization and antioxidant capacity of anchovy by-product protein films enriched with rosemary and laurel essential oils. Ege Journal of Fisheries and Aquatic Sciences, 37(4), 379-387. DOI:10.12714/egejfas.37.4.09

Abstract: In this study, characterization and antioxidant capacity of anchovy by-product protein (ABP) films with $0.5,1.0$ and $1.5 \%$ rosemary (REO) and laurel essential oils (LEO) were investigated. The films with REO and LEO showed higher elongation at break and water vapor permeability (WVP), but lower elastic modulus, transparency, and tensile strength. $L^{*}$ and $b^{*}$ values decreased as a function of essential oil (EO) amount and films became darker and slightly yellowish. The solubility of films with REO and LEO decreased by $10.00-16.05 \%$ and $13.84-18.20 \%$, respectively. Intermolecular interaction and molecular organization in the polymer matrix were changed by EO incorporation. Films with EOs showed a nonhomogeneous surface and comparatively smooth cross-section structure providing easy permeation. The antioxidant properties of films were enriched by addition EO and the highest antioxidant capacity was determined in $1.5 \%$ LEO film. As a result, although ABP films enriched with EOs have a high WVP, they can be used as packaging material for food products that are susceptible to lipid oxidation.

Keywords: Anchovy processing by-product, protein film, antioxidant capacity, rosemary essential oil, laurel essential oil

Öz: Bu çalışmada \%0,5, 1,0 ve 1,5 oranlarında biberiye (BUY) ve defne uçucu yağlarını (DUY) içeren hamsi atık protein (HAP) filmlerin karakterizasyonu ve antioksidan kapasitesi incelenmişstir. BUY veya DUY içeren filmler daha yüksek gerilme ve su buharı geçirgenliği (SBG), fakat daha düşük elastik modül, saydamlık ve kopma uzaması göstermiştir. Uçucu yağ (UY) miktarııı bir fonksiyonu olarak $L^{*}$ ve $b^{*}$ değerleri azalmış ve filmler daha koyu ve hafif sarımsı hale gelmiştir. BUY ve DUY içeren filmlerin çözünürlüğü sırasılyla \%10,00-16,05 ve \%13,84-18,20 düzeyinde azalmıştır. Polimer matristeki moleküller arası etkileşim ve moleküler organizasyon, UY ilavesi ile değiştirimiştir. UY içeren filmler homojen olmayan bir yüzey ve kolay geçirgenlik sağlayan nispeten pürüzsüz bir kesit yapısı göstermiștir. Filmlerin antioksidan özellikleri UY ilavesiyle zenginleștirilmiş ve en yüksek antioksidan kapasite \%1,5 DUY içeren filmde belirlenmiştir. Sonuç olarak, UY içeren HAP filmler yüksek bir SBG' ye sahip olmalarına rağmen, lipit oksidasyonuna duyarlı gıda maddeleri için ambalaj malzemesi olarak kullanılabilirler.

Anahtar kelimeler: Hamsi işleme atığı, protein film, antioksidan kapasite, biberiye uçucu yağı, defne uçucu yağı

\section{INTRODUCTION}

Recently, many researchers have started to conduct researches on biodegradable and/or edible films and coatings produced from natural polymers, which are generally comprised of waste products of fishing, agriculture or livestock raising (Gomez-Estaca et al., 2009). This is thanks to various advantages of these films and coatings such as biodegradability, edibility, barrier properties, biocompatibility and their non-polluting and nontoxic properties (Alparslan et al., 2014). Moreover, they may be used as carriers for antioxidants, antimicrobial agents, color, nutrients, spices and herbs, and may generate localized or delayed activity when needed (Alparslan et al., 2014; Tural and Turhan, 2017). Such polymers can be based on lipid, protein, or polysaccharide: the physical properties of these films may be highly variable, depending on the kind of polymer employed (Gomez-Estaca et al., 2009; Pires et al., 2011). Many researchers have stated that in the development of biodegradable films, proteins extracted from fish by-products have been successfully used among these materials (Pires et al., 2011; Teixeira et al., 2014; Zavareze et al., 2014). Moreover, it is also vital that fish-processing by-products are effectively evaluated for the prevention of environmental pollution as well as achieving high added value products by increasing the range of products (Zavareze et al., 2014).

Generally, fish protein films are considered as having limited resistance to water vapor transmission due to being highly polar polymers and also due to their high level of hydrogen bonding and hydroxyl groups (Pires et al., 2011; Rocha et al., 2014). Therefore, researchers have tested many essential oils and extracts obtained from some plants to improve these films' barrier and functional properties. Pires et 
al. (2011) studied biodegradable films, which they prepared thyme essential oil (TEO) and hake proteins: as a result, they found that TEO oil reduced the water vapor permeability and enriched the antioxidant activity. Arfat et al. (2014) observed improved water vapor permeability after adding basil leaf essential oil into composite films of fish skin gelatin (FSG) blend and fish protein isolate. According to Teixeira et al. (2014), the addition of origanum, garlic and clove essential oils to hake by-product protein films decreased water vapor permeability and broke force and elongation, while increased their free radical scavenging activity.

Rosemary (Rosmarinus officinalis L.) and laurel (Lauris nobilis L.), which have a wide area of usage such as traditional medicines, are naturally grown in Turkey (Alparslan et al., 2014; Turhan et al., 2009). Various researchers have mentioned that essential oils and extracts obtained from rosemary and laurel leaves are effective antioxidants (Alparslan et al., 2014; El et al., 2014; Gomez-Estaca et al., 2009; Turhan et al., 2009). The antioxidant capacity of rosemary comes from its epirosmanol, carnosol, rosmanol, carnosic acid, rosmaridiphenol, rosmadial, rosmarinic acid, isorosmanol and rosmariquinone contents (Turhan et al., 2009), while that of laurel essential oil is related to its eugenol and methyl eugenol contents (El et al., 2014). The addition of rosemary (REO) and laurel essential oils (LEO) into anchovy by-product (ABP) films is expected to give its antioxidant capacity and also enhance its physicochemical properties.

To our knowledge, there is no study on the characterization and antioxidant capacity of ABP films enriched with REO and LEO in the literature. Hence, this study aimed to characterize the ABP films enriched with REO and LEO and to determine their antioxidant capacities.

\section{MATERIALS AND METHODS}

\section{Materials}

Anchovy (Engraulis encrasicolus) processing by-products including head, frame and viscera were obtained from Sastaş A.Ş (Samsun, Turkey) and proteins in by-products were extracted using the method described by Tural and Turhan (2017). The obtained anchovy by-product protein (ABP) powder $(10.41 \pm 0.09 \%$ water, $79.17 \pm 1.25 \%$ protein, $2.11 \pm 0.22 \%$ lipid and $5.15 \pm 0.03 \%$ ash (AOAC, 1990)) was stored in glass jars at $4^{\circ} \mathrm{C}$ until film preparation. Dried rosemary (Rosmarinus officinalis L.) and laurel (Lauris nobilis L.) leaves collected from different geographical regions in Turkey were purchased from a local market (Samsun, Turkey) and authenticated by the experts at the Department of Biology (Ondokuz Mayis University, Samsun, Turkey). The steam distillation method was used to obtain the essential oils of rosemary and laurel using a Clevenger apparatus (Sesim Kimya Laboratuvar, Turkey) as mentioned Tural and Turhan
(2017). Tween 80 and glycerol were purchased from Merck (Germany).

\section{Preparation of films}

The technique described by Limpan et al. (2010) was applied by practicing several modifications to prepare the $A B P$ films. $4.0 \mathrm{~g} A B P$ was blended with $100 \mathrm{~mL}$ distilled water, and the solution $\mathrm{pH}$ was calibrated to 11.5 with $5 \mathrm{M} \mathrm{NaOH}$. Then, glycerol was included up to $40 \%$ (w/w of $A B P$ ) as a plasticizer, and the solution was homogenized for $5 \mathrm{~min}$ at $10,000 \mathrm{rpm}$. Subsequently, it was slowly stirred for $60 \mathrm{~min}$ at $85^{\circ} \mathrm{C}$ to allow film formation, centrifuged for $10 \mathrm{~min}$ at 5,000 $\mathrm{rpm}$, filtered to remove undissolved residuals and cooled to $40 \pm 2^{\circ} \mathrm{C}$. Tween 80 at $0.05 \%(\mathrm{v} / \mathrm{v})$ of essential oil was added as an emulsifier to assist essential oil dispersion in the filmforming solution, then essential oils from rosemary (REO) and laurel (LEO) at 0 (as control), $0.5,1.0$ and $1.5 \%$ (v/v) ratios of film solution were added to the film-forming solution. These rates were selected based on the results of the study by Tural and Turhan (2017). The solution was emulsified for $3 \mathrm{~min}$ at $10,000 \mathrm{rpm}$. Finally, the film-forming emulsion $(50 \mathrm{~g})$ was put into acrylic plates (15cm diameter) and left for drying for $24 \mathrm{~h}$ at $40^{\circ} \mathrm{C}$. Then, the samples of dried films were taken out of the plates and adjusted to $54 \%$ relative humidity for 3 days in a desiccator at room temperature (approx. $25^{\circ} \mathrm{C}$ ).

\section{Characterization of films}

Film thicknesses were measured using a digital micrometer (Insize, 3101-25A model, China) with a precision of $0.001 \mathrm{~mm}$. The results were expressed as the mean of ten measurements on each triplicate film sample at different locations.

The color parameters were measured with Hunter Lab system using a calibrated Minolta CR 400 chromameter (Japan) with a standard illuminant D65 and a $10^{\circ}$ observer of $2.54 \mathrm{~cm}$ aperture size. Hunter $L$ (lightness: $0=$ black and 100 = white), $a$ (redness: $+a=$ red and $-a=$ green) and $b$ (yellowness: $+b=$ yellow and $-b=$ blue) values were recorded. The results were expressed as the mean of five measurements on each triplicate film sample at different locations.

The film transparency values were calculated with the method of Kurt and Kahyaoglu (2014) and the film absorbance was measured at $600 \mathrm{~nm}$ using a UV spectrophotometer (Helios Gama, England). The samples were cut into rectangular pieces based on the lateral area of the spectrophotometer test cell and placed in the test cell. The reference value was determined from an empty test cell. The transparency value of the film was calculated by:

$$
\text { Transparency value }=\frac{\mathrm{Abs}_{600}}{\mathrm{x}}
$$

where Abs600 is the absorbance at $600 \mathrm{~nm}$, and $\mathrm{x}$ is the mean film thickness $(\mathrm{mm})$. According to this equation, higher transparency values imply lower transparency. All 
measurements were performed on each triplicate film sample at five different locations.

The water vapor permeability (WVP) values were obtained by the ASTM E96-05 gravimetric method (ASTM, 2005). The films (14 mm diameter) were sealed in glass cups containing silica gels $(0 \% \mathrm{RH})$. They were stored at $25^{\circ} \mathrm{C}$ in desiccators containing distilled water $(100 \% \mathrm{RH})$. The glass cups were weighed every $1 \mathrm{~h}$ for $8 \mathrm{~h}$ and WVP of the films was calculated by:

$$
\mathrm{SBG}=\frac{\mathrm{w}}{\mathrm{t}} \times \frac{\mathrm{x}}{\Delta P \times \mathrm{A}}
$$

where $w / t$ is determined according to linear regression $\left(R^{2}>0.99\right)$ from the water absorbed by the system until the steady-state was reached, $x$ is the mean sample thickness. A is the film area exposed to moisture transfer $\left(1.539 \times 10^{-4} \mathrm{~m}^{2}\right)$, and $\Delta P$ is the partial pressure difference of the film at $25^{\circ} \mathrm{C}(\mathrm{kPa})$. All the measurements for each of the films were completed in triplicates.

The method described by Gennadios et al. (1998) was used to measure the solubility in water of the different $A B P$ films. The initial dry matter of the preconditioned film pieces $(20 \mathrm{~mm} \times 20 \mathrm{~mm})$ was determined by drying in an aircirculating oven at $105^{\circ} \mathrm{C}$ for $24 \mathrm{~h}$. Afterward, the film pieces were immersed in $50 \mathrm{~mL}$ distilled water containing sodium azide $(0.1 \%, \mathrm{w} / \mathrm{v})$ and stored for $24 \mathrm{~h}$ at room temperature (approx. $25^{\circ} \mathrm{C}$ ) under periodic agitation. To determine the final dry weight, insoluble matter was separated carefully and left for drying for $24 \mathrm{~h}$ at $105^{\circ} \mathrm{C}$. Solubility was determined as the percent weight loss of the film pieces from the immersing. The tests were performed in triplicate.

Tensile strength (TS), elongation at break (EAB) and elastic modulus (EM) were determined using a texture analyzer (TA-XT2 Texture Analyzer, UK) according to the ASTM standard method D882-09 (ASTM, 2009). The films were cut into strips $(1 \mathrm{~cm} \times 4 \mathrm{~cm})$ and conditioned for 3 days (54\% RH). The distance and force were measured during the extension of the strips mounted between the grips at $1.5 \mathrm{~mm} / \mathrm{s}$ until break. TS was calculated by dividing the load at break by the original cross-sectional area $\left(\mathrm{mm}^{2}\right)$ of the film. Before testing, the strip thicknesses were recorded at ten points, and the cross-sectional area of the film samples was estimated based on the average values. EAB (\%) was calculated by dividing the elongation at the moment of rupture by the initial gauge length and then multiplying by 100 . Moreover, EM was calculated by drawing a tangent to the initial linear portion of the stress-strain curve, selecting any point on this tangent, and dividing the tensile stress by the corresponding strain. The results are expressed as the mean of five samples for each type of film.

The FTIR spectra of the films were recorded at wavenumber range 650 and $4000 \mathrm{~cm}^{-1}$ using a FTIR spectrometer (Perkin Elmer, Model Spectrum Two, USA). Totally 32 scans were carried out at $4 \mathrm{~cm}^{-1}$ resolution. Before analysis, a desiccator containing silica gel was used to condition the film samples at room temperature (approx. $25^{\circ} \mathrm{C}$ ) for 2 weeks to achieve the maximum dehydration of the films.

Cross-section and surface characteristics of the film samples were visualized with a scanning electron microscope (JEOL, JSM-7001F model, Japan) at $10 \mathrm{kV}$ increasing voltage. Before the visualization process, the samples were coated with gold-palladium palladium (Quorum SC7620, Laughton, UK), and photographs were taken at $1500 \mathrm{x}$ magnification.

The calorimetric analysis was performed using a differential scanning calorimeter (Perkin Elmer, DSC 4000 model, USA). Before analysis, film samples were kept for 2 weeks at room temperature (approx. $25^{\circ} \mathrm{C}$ ) in a desiccator containing silica gel for dehydrating the films. A sample, weighing $5 \mathrm{mg}$ was put into aluminum pans, sealed, and scanned under nitrogen at $10{ }^{\circ} \mathrm{C} / \mathrm{min}$ over the range of $50 /+120^{\circ} \mathrm{C}$. An empty aluminum pan was used as a reference.

\section{Antioxidant capacity of films}

The antioxidant capacity of ABP films enriched with REO and LEO was determined with methods of ferric reducing antioxidant power (FRAP) (Gao et al. 2000) and 2,2-diphenyl2-picrylhydrazyl (DPPH) scavenging activity (Nakajima et al. 2004). For the FRAP determination, $50 \mu \mathrm{L}$ film solution containing $0.15 \mathrm{~g}$ film and $1.5 \mathrm{~mL}$ methanol was mixed with $0.95 \mathrm{~mL}$ ferric-2,4,6-tripyridil-s-triazine (TPTZ) reagent (which was done by mixing $300 \mathrm{mM}$ acetate buffer, $\mathrm{pH} 3.6,10 \mathrm{mM}$ TPTZ in $40 \mathrm{mM} \mathrm{HCl}$ and $20 \mathrm{mM} \mathrm{FeCl}_{3}$ at the ratio 10:1:1). Then, the sample absorbance was read at $593 \mathrm{~nm}$ after 30 min incubation at room temperature (approx. $25^{\circ} \mathrm{C}$ ) using a UV-Vis spectrophotometer (Helios Gama, England). FRAP values were determined according to Trolox standard curves and expressed as $\mathrm{mg}$ Trolox/mL.

For the DPPH scavenging activity determination, $0.15 \mathrm{~g}$ of ABP film sample was dissolved in $1.5 \mathrm{~mL}$ methanol. Afterward, $10 \mu \mathrm{L}$ of film solution was mixed with $40 \mu \mathrm{L}$ of methanol and $1 \mathrm{~mL}$ of DPPH methanol solution $(100 \mu \mathrm{M})$. Following vigorous shaking, the mixture was left at room temperature (approx. $25^{\circ} \mathrm{C}$ ) for $30 \mathrm{~min}$ and then, the sample absorbance was recorded at $517 \mathrm{~nm}$ with a UV-Vis spectrophotometer (Helios Gama, England). DPPH scavenging activity was calculated by:

$$
\text { DPPH scavenging activity (\%) } \frac{\mathrm{A}_{\text {blank }}-\mathrm{A}_{\text {sample }}}{\mathrm{A}_{\text {blank }}} \times 100
$$

where Ablank is the absorbance of the control, and Asample is the absorbance of the test sample.

\section{Statistical analysis}

Experiments were conducted as triplicates and expressed as mean \pm standard deviation. Analysis of variance (ANOVA) was used to obtain the data and Duncan's multiple range test 
was used to compare the main differences among the means. SPSS statistical package program (SPSS 17.0 for windows, SPSS Inc., Chicago, IL, USA) was preferred for the analysis with a significance level of 0.05 .

\section{RESULTS AND DISCUSSION}

\section{Characterization of films}

The thickness values of films varied from $0.196 \mathrm{~mm}$ to $0.205 \mathrm{~mm}$, and the addition of different essential oils had no notable effect $(p>0.05)$ (Table 1$)$. According to Tural and Turhan (2017), the film thickness is influenced by the solid content of the film-forming solution. The addition of essential oils to the film-forming solution at low concentrations probably did not affect film thicknesses. These results were in line with the findings of Zinoviadou et al. (2009), showing that the addition of oregano oil at $0.5,1.0$ and $1.5 \%$ has no significant impact on the thickness of whey protein isolate (WPI) films. Similar results were also detected by Tural and Turhan (2017) in ABP films containing TEO. However, Jouki et al. (2014) reported that the addition of thyme essential oil to the filmforming emulsion led to an increase in the thickness of quince seed mucilage films, but this effect was only significant at the highest level of TEO used (2\%).

In this study, lightness, redness and yellowness values of control film, measured as $L^{*}, a^{*}$ and $b^{*}$, were determined to be $33.38,33.66$ and 54.15 , respectively. Addition of REO and LEO significantly $(p<0.05)$ affected $L^{*}, a^{*}$ and $b^{*}$ values of ABP films and in general, $L^{*}$ and $b^{*}$ values decreased as a function of essential oil amount. Hence, films containing essential oil at higher amounts became darker and slightly yellowish as indicated by lower $L^{*}$ and $b^{*}$ values. The films enriched with both REO and LEO showed higher $a^{*}$ values when compared to the control film (Table 1). The color differences produced by REO and LEO are probably caused by the high-level presence of the phenolic compounds in essential oils. Similar changes in film color were also observed by Shojaee-Aliabadi et al. (2014) and Baek et al. (2018) in k-carrageenan films at different levels of Zataria multiflora Boiss and Mentha pulegium essential oils and alginate films containing various concentrations $(0 \%, 0.4 \%$, $0.7 \%$, and $1.0 \%$ ) of cinnamon essential oils, respectively.

Table 1. Thickness, color and transparency values of anchovy by-product protein films enriched with rosemary and laurel essential oils

\begin{tabular}{lccccc}
\hline \multirow{2}{*}{ Films } & \multirow{2}{*}{ Thickness, $\mathbf{m m}$} & \multicolumn{3}{c}{ Color properties } & \multirow{2}{*}{ Transparency } \\
\cline { 3 - 5 } & & $\mathbf{L}^{*}$ & $\mathbf{a}^{*}$ & $\boldsymbol{b}^{*}$ & \\
\hline Control & $0.205 \pm 0.010^{\mathrm{a}}$ & $33.38 \pm 1.19^{\mathrm{d}}$ & $33.66 \pm 1.26^{\mathrm{c}}$ & $54.15 \pm 1.51^{\mathrm{c}}$ & $1.28 \pm 0.01^{\mathrm{d}}$ \\
$0.5 \%$ REO & $0.199 \pm 0.003^{\mathrm{a}}$ & $38.36 \pm 0.10^{\mathrm{b}}$ & $38.71 \pm 0.36^{\mathrm{a}}$ & $60.54 \pm 2.06^{\mathrm{b}}$ & $1.35 \pm 0.14^{\mathrm{d}}$ \\
$1.0 \%$ REO & $0.201 \pm 0.002^{\mathrm{a}}$ & $34.97 \pm 0.81^{\mathrm{c}}$ & $38.67 \pm 0.09^{\mathrm{a}}$ & $52.49 \pm 2.42^{\mathrm{cd}}$ & $1.63 \pm 0.29^{\mathrm{c}}$ \\
$1.5 \%$ REO & $0.197 \pm 0.004^{\mathrm{a}}$ & $32.70 \pm 0.75^{\mathrm{d}}$ & $38.32 \pm 0.38^{\mathrm{a}}$ & $49.18 \pm 0.76^{\mathrm{e}}$ & $1.92 \pm 0.07^{\mathrm{ab}}$ \\
$0.5 \%$ LEO & $0.198 \pm 0.003^{\mathrm{a}}$ & $40.32 \pm 0.43^{\mathrm{a}}$ & $35.73 \pm 0.10^{\mathrm{b}}$ & $66.62 \pm 1.71^{\mathrm{a}}$ & $1.70 \pm 0.04^{\mathrm{bc}}$ \\
$1.0 \%$ LEO & $0.196 \pm 0.004^{\mathrm{a}}$ & $38.34 \pm 0.15^{\mathrm{b}}$ & $35.38 \pm 0.10^{\mathrm{b}}$ & $52.25 \pm 0.53^{\mathrm{cd}}$ & $1.76 \pm 0.10^{\mathrm{bc}}$ \\
$1.5 \%$ LEO & $0.197 \pm 0.002^{\mathrm{a}}$ & $37.97 \pm 0.66^{\mathrm{b}}$ & $35.16 \pm 0.38^{\mathrm{b}}$ & $50.36 \pm 1.41^{\text {de }}$ & $2.10 \pm 0.05^{\mathrm{a}}$ \\
\hline
\end{tabular}

The results represent means $\pm S D$ of three replicates. Means in same column with different superscripts are significantly different $(p<0.05) . L^{*}=$ lightness/brightness (100: white, 0 : black); $a^{*}=$ redness/greenness (+, red; -, green); $b^{*}=$ yellowness/blueness (+, yellow; -, blue); REO = rosemary essential oil; LEO = laurel essential oil.

While ABP films that have no essential oil appeared transparent, the addition and amount of REO and LEO significantly affect $(p<0.05)$ the transparency values of the films. The films enriched with both REO and LEO exhibited higher transparency values compared to the control and in general, an increase in REO and LEO amounts significantly $(p<0.05)$ raised the transparency values of the ABP films (Table 1). Higher transparency values show lower transparency. Therefore, transparency of the films decreased as the amount of the essential oils increased, probably because of an increase in light-scattering caused by oil droplets in the film network. Generally, the level and particle size of the dispersed phase affect the light-scattering: with more droplets, greater intensity in light-scattering and lower transparency is obtained (Shojaee-Aliabadi et al., 2014). The results of this study show that films enriched and un-enriched with essential oils were colored, but they have suitable transparencies for food packaging. Shojaee-Aliabadi et al. (2013, 2014) and Tural and Turhan (2017) reported similar results in $\mathrm{k}$-carrageenan films containing plant essential oils and in ABP films treated with TEO, respectively. Water vapor permeability (WVP) values of films changed between 1.54 and $2.08 \mathrm{~g} . \mathrm{mm} / \mathrm{m}^{2} . \mathrm{h} . \mathrm{kPa}$, and the addition of REO and LEO significantly $(p<0.05)$ increased it (Table 2). This increase was higher in films enriched with REO. Several factors may affect the WVP of films such as film thickness, the hydrophilichydrophobic ratio of the film components, water sensitivity and crystallinity (Jouki et al., 2014). The differences in the hygroscopic nature of the oils might lead to an increase in the WVP values of the film treated with essential oils causing different abilities to attract water to the film network. Additionally, results obtained from SEM images (Figure 2) and DSC thermograms (Figure 3) showed that REO and LEO presence led to less crystalline films, causing an increase in WVP. As known, high crystallinity, polymers are generally less permeable because of their ordered structure (Jouki et al., 2014). Results found by Mei et al. (2013) and Tural and Turhan (2017) showed very good similarity in water chestnut starch-chitosan films treated with pine needle essential oil (PNEO) and in ABP films with TEO, respectively. However, 
Zinoviadou et al. (2009) mentioned that the addition of oregano essential oil $(0.5,1.0$ and $1.5 \%)$ into the WPI film matrix did not affect significantly the WVP.

The highest solubility with the percentage of 63.41 was observed in the control film, whereas films with REO and LEO showed lower solubility $(51.87-57.07 \%$ ) (Table 2). The solubility values of ABP films treated with REO and LEO decreased by $10.00-16.05 \%$ and $13.84-18.20 \%$, respectively, compared to the control. Additive effects on the solubility of films usually depend on the sort of compounds and concentrations as well as their natural hydrophilicity and hydrophobicity indices (Ghasemlou et al., 2013). The decrease in solubility might be due to the decrease in the hydrophilic nature of the films and the interaction between the components of REO and LEO, as well as the hydroxyl groups of ABP. Similar results were found by Ghasemlou et al. (2013) in corn starch films incorporated with plant essential oils and by Shojaee-Aliabadi et al. (2013) in K-carrageenan films containing Saturaje hortensis essential oil.

Table 2. WVP, solubility and mechanical properties of anchovy by-product protein films enriched with rosemary and laurel essential oils

\begin{tabular}{lccccc}
\hline Films & $\begin{array}{c}\text { WVP, } \\
\text { g.mm/m².h.kPa }\end{array}$ & Solubility, \% & TS, MPa & EAB, \% & EM, MPa \\
\hline Control & $1.54 \pm 0.10^{\mathrm{d}}$ & $63.41 \pm 0.44^{\mathrm{a}}$ & $1.46 \pm 0.04^{\mathrm{a}}$ & $51.50 \pm 2.15^{\mathrm{e}}$ & $10.77 \pm 1.15^{\mathrm{a}}$ \\
$0.5 \%$ REO & $2.04 \pm 0.04^{\mathrm{a}}$ & $57.07 \pm 3.42^{\mathrm{b}}$ & $0.62 \pm 0.01^{\mathrm{b}}$ & $97.57 \pm 4.34^{\mathrm{b}}$ & $2.77 \pm 0.25^{\mathrm{bc}}$ \\
$1.0 \%$ REO & $2.08 \pm 0.11^{\mathrm{a}}$ & $54.99 \pm 4.26^{\mathrm{bc}}$ & $0.60 \pm 0.01^{\mathrm{b}}$ & $99.16 \pm 3.44^{\mathrm{ab}}$ & $3.27 \pm 0.42^{\mathrm{b}}$ \\
$1.5 \%$ REO & $1.90 \pm 0.08^{\mathrm{b}}$ & $53.23 \pm 2.97^{\mathrm{bc}}$ & $0.58 \pm 0.05^{\mathrm{bc}}$ & $105.40 \pm 4.54^{\mathrm{a}}$ & $2.67 \pm 0.06^{\mathrm{bc}}$ \\
$0.5 \%$ LEO & $1.75 \pm 0.02^{\mathrm{c}}$ & $54.63 \pm 0.74^{\mathrm{bc}}$ & $0.53 \pm 0.02^{\mathrm{c}}$ & $64.94 \pm 3.72^{\mathrm{d}}$ & $3.20 \pm 0.10^{\mathrm{b}}$ \\
$1.0 \%$ LEO & $1.79 \pm 0.08^{\mathrm{bc}}$ & $52.86 \pm 1.35^{\mathrm{bc}}$ & $0.47 \pm 0.04^{\mathrm{d}}$ & $72.40 \pm 2.09^{\mathrm{c}}$ & $1.87 \pm 0.12^{\mathrm{c}}$ \\
$1.5 \%$ LEO & $1.80 \pm 0.02^{\mathrm{bc}}$ & $51.87 \pm 0.21^{\mathrm{c}}$ & $0.47 \pm 0.01^{\mathrm{d}}$ & $78.76 \pm 4.87^{\mathrm{c}}$ & $2.20 \pm 0.10^{\mathrm{c}}$ \\
\hline
\end{tabular}

The results represent means $\pm S D$ of three replicates. Means in same column with different superscripts are significantly different $(p<0.05)$. WVP $=$ water vapor permeability; $T S$ = tensile strength; $E A B=$ elongation at break; $E M=$ elastic modulus; $R E O=$ rosemary essential oil; $L E O=$ laurel essential oil.

Mechanical features of the film were obtained by using the values of TS, EAB, and EM. The ABP film without essential oils had a tensile strength of $1.46 \mathrm{MPa}$, which agrees with that found by Tural and Turhan (2017). The addition of REO or LEO into the films led to a decrease in TS and $E M$ values, but an increase in EAB values. TS and EM values of the samples enriched with REO did not importantly change after the increase of the essential oil level from 0.5 to $1.5 \%$, but TS and EM values of films treated with LEO significantly changed after the increase in the level from 0.5 to $1.0 \%$ (Table 2). Thus, essential oils led the films to become weaker, and less resistant to break, depending on the essential oil level. The partial replacement of stronger polymer-polymer interactions by weaker polymer-oil interactions in the film network in the presence of the essential oil may primarily explain this effect, which, in turn, may lead to the weakening of the network structure, and hence the TS of the ABP film. Moreover, a plasticizing effect was caused by the changes in the interaction balances, even at small concentrations of essential oils, making the film more stretchable (high EAB value) (Shojaee-Aliabadi et al., 2013; Tural and Turhan, 2017). Rojas-Grau et al. (2007) found a decrease in TS and EM values, and an increase in $E A B$ values of alginate-apple puree edible films treated with essential oils (oregano, lemongrass and cinnamon), and this finding complies with the results of this study. Other researchers (Ghasemlou et al., 2013; Shojaee-Aliabadi et al., 2013, 2014; Tural and Turhan, 2017) also obtained similar results in edible films combined with plant essential oils.

Generally, FTIR spectra of all film samples had similar major peaks, but the peak amplitudes changed based on the level of the added essential oils (Figure 1). In all samples, the band was found at the $1043 \mathrm{~cm}^{-1}$ wavenumber, matching to the $\mathrm{OH}$ group, mostly due to the glycerol added as a plasticizer (Hosseini et al., 2015; Tongnuanchan et al., 2013; Tural and Turhan, 2017). The amplitude of this peak decreased with an increase in the level of added essential oils and this might be attributed to the dilution effect of the essential oils. A similar peak at the wavenumber of 1042$1045 \mathrm{~cm}^{-1}$ for fish gelatin-chitosan biocomposite films treated with different concentrations of Origanum vulgare L. essential oil was reported by Hosseini et al. (2015) and at the wavenumber of $1043 \mathrm{~cm}^{-1}$ for $\mathrm{ABP}$ films enriched with different concentrations of TEO was reported by Tural and Turhan (2017). All films showed major peaks at 1540-1547 $\mathrm{cm}^{-1}$ (amide-II, arising from bending vibration of $\mathrm{N}-\mathrm{H}$ groups and stretching vibrations of C-N groups), $1624-1628 \mathrm{~cm}^{-1}$ (amide-l, presenting $\mathrm{C}=0$ stretching/hydrogen bonding coupled with $\mathrm{COO}$ ) and $1235-1237 \mathrm{~cm}^{-1}$ (amide-III, displaying the vibrations in plane of $\mathrm{C}-\mathrm{N}$ and $\mathrm{N}-\mathrm{H}$ groups of bound amide or vibrations of $\mathrm{CH}_{2}$ groups of glycine) wavenumbers (Arfat et al., 2014; Tongnuanchan et al., 2013). In general, the amplitudes of films decreased as the essential oil level increased and the highest amplitudes for amide-I, II and III were observed in control films. This result could be attributed to the highest protein content in the control.

In all samples, amide-A peak was observed at 3273-3276 $\mathrm{cm}^{-1}$ wavenumber and amide-B peak at 2918-2924 $\mathrm{cm}^{-1}$. Amide-A peak shows the $\mathrm{NH}$-stretching accompanied by hydrogen bonding, while amide-B peak shows the asymmetric stretching vibration of $\mathrm{CH}$ and $\mathrm{NH}_{3}{ }^{+}$(Arfat et al., 2014). The amplitude of amide-A peak decreased when the films were treated with REO and LEO, especially at $1.5 \%$ level. Lower interaction between $\mathrm{ABP}$ confirmed this phenomenon, as expressed by lower TS with increasing $E A B$ when essential oils were incorporated at higher levels. Peaks with 
wavenumber of $2851 \mathrm{~cm}^{-1}$ (methylene symmetric $\mathrm{C}-\mathrm{H}$ stretching) and $2871 \mathrm{~cm}^{-1}$ (methyl asymmetric $\mathrm{C}-\mathrm{H}$ stretching) were also obtained in all film samples. The amplitude of peak at wavenumber $2851 \mathrm{~cm}^{-1}$ increased, while the amplitude of peak at wavenumber $2871 \mathrm{~cm}^{-1}$ decreased when essential oils were added to the films. It was observed that methylene symmetric stretching bands at approximately $2851 \mathrm{~cm}^{-1}$ were present in most lipids, while methyl asymmetric stretching bands at approximately $2871 \mathrm{~cm}^{-1}$ were present in most proteins (Tongnuanchan et al., 2013). Furthermore, a peak with $1737 \mathrm{~cm}^{-1}$ wavenumber was observed in the films with essential oils and the amplitude of this peak increased with the essential oil amount. This probably presented the $\mathrm{C}=0$ stretching vibration of aldehyde or ester carbonyl groups. Ketone, ester, and aldehyde are the primary chemical groups in essential oils (Arfat et al., 2014). However, no peak at 1737 $\mathrm{cm}^{-1}$ wavenumber was observed in the control. Similar peaks at 1733-1743 wavenumbers were found by Tongnuanchan et al. (2014) in fish gelatin films with citronella and basil essential oils. The FTIR spectra results showed that REO and LEO addition changed the molecular organization and intermolecular interaction in the polymer matrix

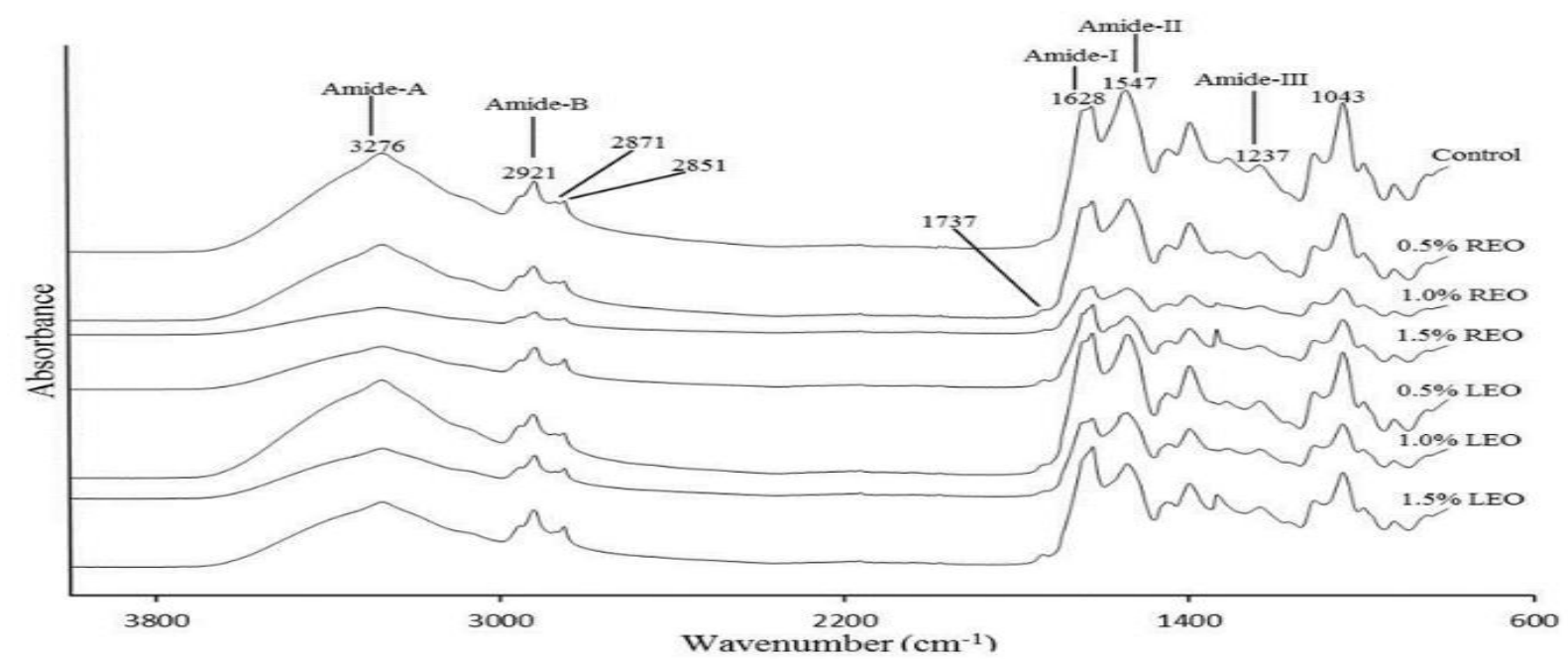

Figure 1. FTIR spectra of anchovy by-product protein films incorporated with rosemary and laurel essential oils

The addition and amount of REO and LEO affected the film structures (Figure 2). The control film gave a homogeneous and continuous surface, whereas ABP films enriched with REO and LEO showed a heterogeneous surface. Also, a great number of granules were observed in the surface of ABP films with REO and LEO, and in general, the size of granules increased as the essential oil level increased. Hereby, the permeability of surface containing granules facilitated and resulted in an increase in WVP of films treated with EO. Similar surface images were observed by Tongnuanchan et al. (2013) in the FSG films with root essential oils and by Tural and Turhan (2017) in ABP films treated with TEO. The control film showed a nonhomogeneous, compact and rough cross-section structure, while films enriched with REO and LEO showed a relatively smooth cross-section structure. The presence of REO and LEO probably led to discontinuance with lipid droplets or holes present in the protein network and this may be the reason for the higher WVP values of the films treated with EOs. Mei et al. (2013) also observed similar results after adding PNEO to the water chestnut starch-chitosan edible films. DSC thermograms of all films showed similar behaviour and exhibited clearly endothermic peaks at the phase- transition temperature $(\mathrm{Tm})$ ranges of $53.53-56.37^{\circ} \mathrm{C}$. (Figure 3).

These peaks were most probably related to the denaturation temperature of myosin and actin as observed by Rocha et al. (2013). These researchers in their studies with Argentine anchovy (Engraulis encrasicholus) protein isolate observed the endothermic peak at $62.2{ }^{\circ} \mathrm{C}$. Temperature differences for endothermic peaks could be attributed to fish species, kind of muscle and heating conditions. Except films containing 1.5\% LEO, ABP films enriched with REO and LEO showed slightly higher Tm compared to control film containing $4 \% \mathrm{ABP}$ and $40 \%$ glycerol, which may be by the reason of more hydrophobic nature and the larger molecular weight of REO and LEO compared to glycerol. Jouki et al. (2014) observed similar results in QSM films with thyme and Tongnuanchan et al. (2014) in fish gelatin films with basil and citronella. The highest glass-transition temperature $(\mathrm{Tg})$ was seen in the control film as $-24.27{ }^{\circ} \mathrm{C}$ and this temperature was likely associated with $\mathrm{Tg}$ of the glycerol-rich phase. The addition of $0.5 \%$ REO and LEO into the ABP films resulted in lower $\operatorname{Tg}\left(-37.08\right.$ and $-33.82{ }^{\circ} \mathrm{C}$, respectively) (data not shown). 
However, $\mathrm{Tg}$ of films enriched with 1.0 and 1.5\% REO and LEO most likely became too low to be observed in the tested temperature range. For film flexibility, a lower $\mathrm{Tg}$ is better. In general, $\mathrm{Tg}$ of the protein films increases with an increase in the chain stiffness assisted by inter/intramolecular attractive forces; therefore, the addition of essential oils improves the weak structure of films (Tongnuanchan et al., 2014). In general, the DSC results were also in line with the mechanical properties of films (Table 2). An increase in $\mathrm{Tg}$ of edible films with increasing essential oil levels was also observed by Jouki et al. (2014).

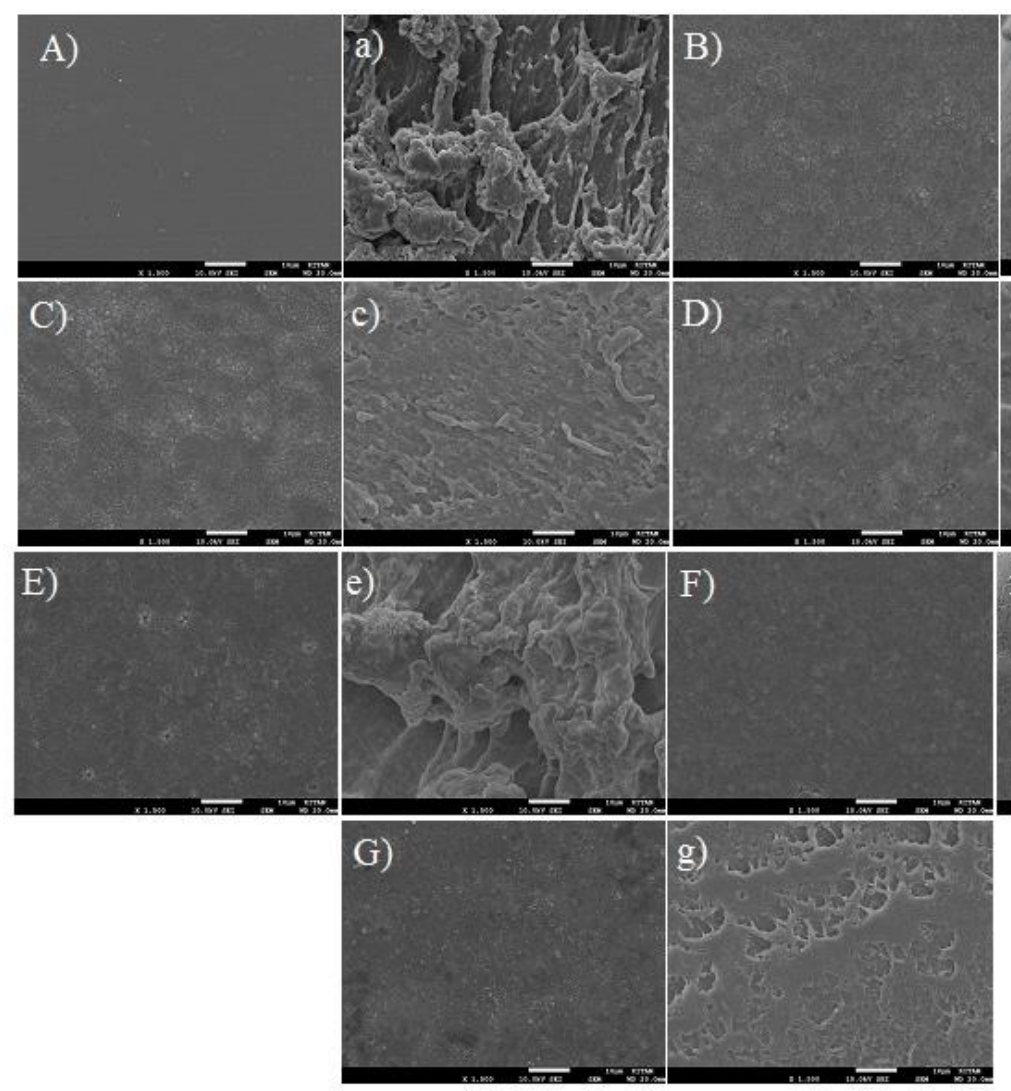

Figure 2. SEM images of the surface $[A$ ) control, B) $0.5 \%$ REO, C) $1.0 \% R E O, D) 1.5 \%$ REO, E) $0.5 \%$ LEO, F) $1.0 \%$ LEO, G) $1.5 \%$ LEO] and cross-section [a) control, b) $0.5 \%$ REO, c) $1.0 \%$ REO, d) $1.5 \%$ REO, e) $0.5 \%$ LEO, f) $1.0 \%$ LEO, g) $1.5 \%$ LEO] of anchovy by-product protein films incorporated with rosemary and laurel essential oils

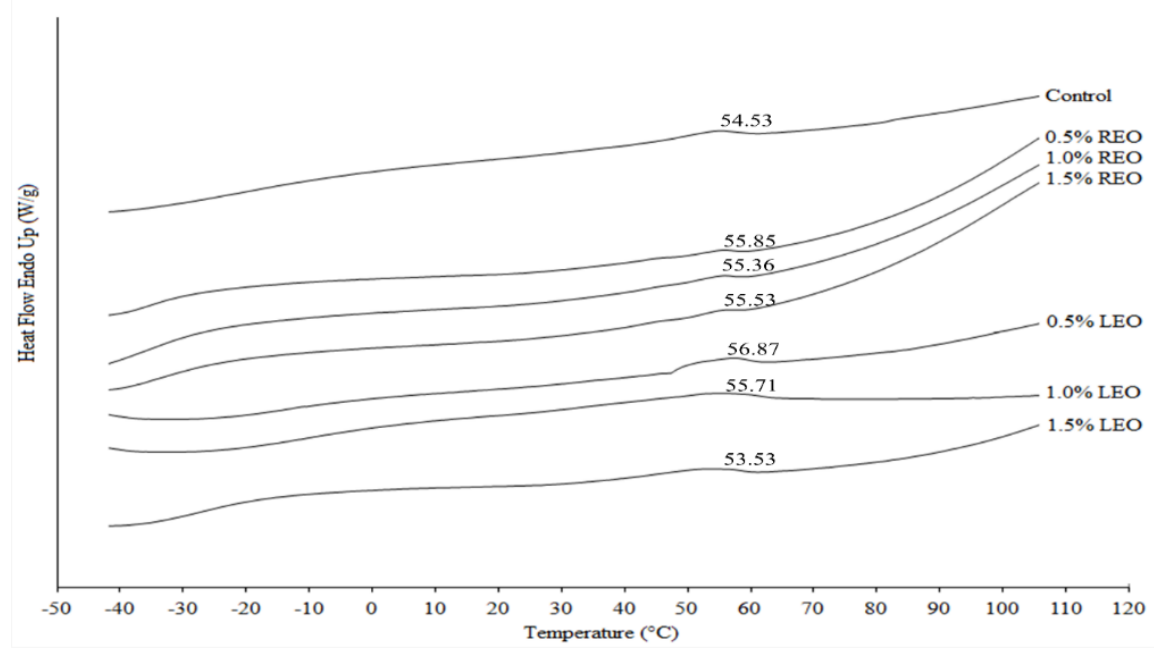

Figure 3. DSC thermograms of anchovy by-product protein films incorporated with rosemary and laurel essential oils 


\section{Antioxidant capacity of films}

Experimental results pointed out that the addition of REO and LEO significantly $(p<0.05)$ affected FRAP and DPPH scavenging activity values (Table 3 ), and the control film exhibited slight antioxidant capacity $(0.91 \mathrm{mg}$ Trolox $/ \mathrm{mL}$ FRAP and $0.06 \% \mathrm{DPPH})$, probably due to the presence of free sulfhydryl groups and amino acids such as Trp, Met and Tyr on ABP as reported by Gencbay and Turhan (2016).

The antioxidant capacity of control ABP film was considerably improved by incorporating both REO and LEO, and in general, an increase in REO and LEO levels increased the antioxidant capacity values of films. Hake protein films treated with TEO (Pires et al., 2011) and FSG films formulated with root essential oils (Tongnuanchan et al., 2013) showed similar results. However, films with LEO exhibited significantly $(p<0.05)$ higher FRAP and DPPH scavenging activity compared to the films with REO at the same level. This could be due to various major components of essential oils, the intensity of possible interactions between the constituents of film and their phenolic compounds, which is greater in the samples with REO.

Table 3. Antioxidant capacity of anchovy by-product protein films enriched with rosemary and laurel essential oils

\begin{tabular}{lcc}
\hline Films & $\begin{array}{c}\text { FRAP, } \mathrm{mg} \\
\text { Trolox/mL }\end{array}$ & $\begin{array}{c}\text { DPPH scavenging } \\
\text { activity, } \%\end{array}$ \\
\hline Control & $0.91 \pm 0.01^{\mathrm{e}}$ & $0.06 \pm 0.03^{\mathrm{d}}$ \\
$0.5 \%$ REO & $1.99 \pm 0.13^{\mathrm{d}}$ & $9.12 \pm 0.56^{\mathrm{c}}$ \\
$1.0 \%$ REO & $2.09 \pm 0.03^{\mathrm{cd}}$ & $9.48 \pm 0.79^{\mathrm{c}}$ \\
$1.5 \%$ REO & $2.13 \pm 0.06^{\mathrm{bcd}}$ & $10.05 \pm 0.89^{\mathrm{bc}}$ \\
$0.5 \%$ LEO & $2.19 \pm 0.13^{\mathrm{bc}}$ & $10.56 \pm 0.01^{\mathrm{b}}$ \\
$1.0 \%$ LEO & $2.27 \pm 0.04^{\mathrm{b}}$ & $10.71 \pm 0.24^{\mathrm{b}}$ \\
$1.5 \%$ LEO & $2.37 \pm 0.06^{\mathrm{a}}$ & $11.63 \pm 0.18^{\mathrm{a}}$ \\
\hline
\end{tabular}

The results represent means $\pm S D$ of three replicates. Means in same column with different superscripts are significantly different $(p<0.05)$. FRAP $=$ ferric reducing antioxidant power; DPPH $=$ 2,2-diphenyl-2-picrylhydrazyl; REO = rosemary essential oil; LEO = laurel essential oil.

\section{REFERENCES}

Alparslan, Y., Baygar, T., Baygar, T., Hasanhocaoglu, H. \& Metin, C. (2014). Effects of gelatin-based edible films enriched with laurel essential oil on the quality of rainbow trout (Oncorhynchus mykiss) fillets during refrigerated storage. Food Technology and Biotechnology, 52, 325-333.

AOAC. (1990). Official method of analysis (15th ed.). Washington, DC: Association of Official Analytical Chemists.

Arfat, Y. A., Benjakul, S., Prodpran, T. \& Osako, K. (2014). Development and characterization of blend films based on fish protein isolate and fish skin gelatin. Food Hydrocolloids, 39, 58-67. DOI:10.1016/j.foodhyd.2013.12.028

ASTM. (2009). Standard test method for tensile properties of thin plastic sheeting (D882-09). In Annual Book of ASTM Standards. American Society for Testing and Materials, Philadelphia, PA.

ASTM. (2005). Standard test method for water vapor transmission of materials (E96-05). In Annual Book of ASTM Standards. American Society for Testing and Materials, Philadelphia, PA.
The highest FRAP and DPPH scavenging activity values were determined in films treated with $1.5 \%$ LEO as $2.37 \mathrm{mg}$ Trolox $/ \mathrm{mL}$ and $11.63 \%$, respectively. Alparslan et al. (2014) presented that gelatin films enriched with LEO had the high antioxidant capacity and inhibited the lipid oxidation of trout fillets. It is considered that the antioxidant capacity of LEO related to its eugenol and methyl eugenol content (El et al., 2014). In line with our results, numerous authors have observed that extracts and essential oils of rosemary and laurel have the strong antioxidant capacity (El et al., 2014; Gomez-Estaca et al., 2009; Turhan et al., 2009).

\section{CONCLUSION}

Our findings in the present study show that $L^{*}$ and $b^{*}$ values decreased as a function of essential oil level and films became darker and yellowish. The incorporation of REO or LEO into the films caused to a decrease in transparency, solubility, TS and EM values, but an increase in $a^{*}$ value, WVP, and EAB value, depending on the essential oil type and level. The FTIR spectra results demonstrated that the addition of REO and LEO changed the molecular organization and intermolecular interaction in the polymer matrix. The control film showed a homogeneous and continuous surface, while the films enriched with REO and LEO showed a heterogeneous. Slightly higher phase-transition and lower glass-transition temperatures were obtained in films treated with EOs. The antioxidant capacity of the film was considerably improved by incorporating both REO and LEO. These results suggested that $A B P$ films enriched with REO and LEO could be suitable for the packaging of food products that are susceptible to lipid oxidation.

\section{ACKNOWLEDGEMENTS}

Some part of this study was taken from $\mathrm{PhD}$ thesis of Serpil Tural and supported by the Scientific and Technological Research Council of Turkey (TUBITAK) (Project No. 1140854). The authors would like to thank TUBITAK for support.

Baek, S. K., Kim, S. \& Song, K, B. (2018). Characterization of Ecklonia cava alginate films containing cinnamon essential oils. International Journal of Molecular Sciences, 19, 3545. DOI:10.3390/ijms19113545

El, S. N., Karagozlu, N., Karakaya, S. \& Sahin, S. (2014). Antioxidant and antimicrobial activities of essential oils extracted from Laurus nobilis L. leaves by using solvent-free microwave and hydrodistillation. Food and Nutrition Sciences, 5, 97-106. DOI:10.4236/fns.2014.52013

Gao, X., Björk, L., Trajkovski, V. \& Uggla, M. (2000). Evaluation of antioxidant actives of rosehip ethanol extracts in different test systems. Journal of the Science of Food and Agriculture, 80, 2021-2027. DOI:10.1002/10970010(200011)80:14<2021::AID-JSFA745>3.0.CO;2-2

Gencbay, G. \& Turhan, S. (2016). Proximate composition and nutritional profile of the Black Sea anchovy (Engraulis encrasicholus) whole fish, fillets and by-products. Journal of Aquatic Food Product Technology, 6 , 864-874. DOI:10.1080/10498850.2014.945199

Gennadios, A., Handa, A., Froning, G.W., Weller, C.L. \& Hanna, M.A. (1998) Physical properties of egg white-dialdehyde starch films. Journal of Agricultural and Food Chemistry, 46, 1297-1302. DOI:10.1021/fif9708047 
Ghasemlou, M., Aliheidari, N., Fahmi, R., Shojaee-Aliabadi, S., Keshavarz, B., Cran, M.J. \& Khaksar, R. (2013). Physical, mechanical and barrier properties of corn starch films incorporated with plant essential oils. Carbohydrate Polymers, 98, 1117-1126.

DOI:10.1016/j.carbpol.2013.07.026

Gomez-Estaca, J., Bravo, L., Gomez-Guillen, M.C., Aleman, A. \& Montero, P. (2009). Antioxidant properties of tuna-skin and bovine-hide gelatin films induced by the addition of oregano and rosemary extracts. Food Chemistry, 112, 18-25. DOI:10.1016/j.foodchem.2008.05.034

Hosseini, S. F., Rezaei, M., Zandi, M. \& Farahmandghavi, F. (2015). Biobased composite edible films containing Origanum vulgare $L$. essential oil. Industrial Crops and Products, 67, 403-413. DOI:10.1016/j.indcrop.2015.01.062

Jouki, M., Mortazavi, S.A., Yazdi, F.T. \& Koocheki, A. (2014). Characterization of antioxidant-antibacterial quince seed mucilage films containing thyme essential oil. Carbohydrate Polymers, 99, 537-546. DOI:10.1016/j.carbpol.2013.08.077

Kurt, A. \& Kahyaoglu, T. (2014). Characterization of a new biodegradable edible film made from salep glucomannan. Carbohydrate Polymers, 104, 50-58. DOI:10.1016/j.carbpol.2014.01.003

Limpan, N., Prodpran, T., Benjakul, S. \& Prasarpran, S. (2010). Properties of biodegradable blend films based on fish myofibrillar protein and polyvinyl alcohol as influenced by blend composition and $\mathrm{pH}$ level. Journal of Food Engineering, 100, 85-92. DOI:10.1016/j.jfoodeng.2010.03.031

Mei, J., Yuan, Y., Guo, Q., Wu, Y., Li, Y. \& Yu, H. (2013). Characterization and antimicrobial properties of water chestnut starch-chitosan edible films. International Journal of Biological Macromolecules, 61, 169-174. DOI:10.1016/j.ijbiomac.2013.06.026

Nakajima, J., Tanaka, I., Seo, S., Yamazaki, M. \& Saito, K. (2004). LC/PDA/ESI-MS profiling and radical scavenging activity of anthocyanins in various berries. Journal of Biomedicine and Biotechnology, 5, 241-247. DOI:10.1155/S1110724304404045

Pires, C., Ramos, C., Teixeira, G., Batista, I., Mendes, R., Nunes, L. \& Marques, A. (2011). Characterization of biodegradable films prepared with hake proteins and thyme oil. Journal of Food Engineering, 105, 422-428. DOI:10.1016/j.jfoodeng.2011.02.036

Rocha, M., Loiko, M.R., Gauterio, G.V., Tondo, E.C. \& Prentice, C. (2013). Influence of heating, protein and glycerol concentrations of film-forming solution on the film properties of Argentine anchovy (Engraulis anchoita) protein isolate. Journal of Food Engineering, 116, 666-673. DOI:10.1016/j.jfoodeng.2013.01.004

Rocha, M., Loiko, M.R., Tondo, E.C. \& Prentice, C. (2014). Physical, mechanical and antimicrobial properties of Argentine anchovy (Engraulis anchoita) protein films incorporated with organic acids. Food Hydrocolloids, 37, 213-220. DOI:10.1016/j.foodhyd.2013.10.017
Rojas-Grau, M., Avena-Bustillos, R. J., Olsen, C., Friedman, M., Henika, P. R., Martin-Belloso, O., Pan, Z. \& McHugh, T. H. (2007). Effects of plant essential oils and oil compounds on mechanical, barrier and antimicrobial properties of alginate-apple puree edible films. Journal of Food Engineering, 81, 634-641. DOI:10.1016/j.jfoodeng.2007.01.007

Shojaee-Aliabadi, S., Hosseini, H., Mohammadifar, M.A., Mohammadi, A., Ghasemlou, M., Ojagh, S.M., Hosseini, S.M. \& Khaksar, R. (2013). Characterization of antioxidant-antimicrobial K-carrageenan films containing Satureja hortensis essential oil. International Journal of Biological Macromolecules, 52, 116-124. DOI:10.1016/j.jijbiomac.2012.08.026

Shojaee-Aliabadi, S., Hosseini, H., Mohammadifar, M.A., Mohammadi, A., Ghasemlou, M., Hosseini, S.M. \& Khaksar, R. (2014). Characterization of K-carrageenan films incorporated plant essential oils with improved antimicrobial activity. Carbohydrate Polymers, 101, 582-591. DOI:10.1016/j.carbpol.2013.09.070

Teixeira, B., Marques, A., Pires, C., Ramos, C., Batista, I., Saraiva, J. A. \& Nunes, M. L. (2014). Characterization of fish protein films incorporated with essential oils of clove, garlic and origanum: physical, antioxidant and antibacterial properties. LWT-Food Science and Technology, 59, 533-539. DOI:10.1016/j.Iwt.2014.04.024

Tongnuanchan, P., Benjakul, S. \& Prodpran, T. (2013). Physico-chemical properties, morphology and antioxidant activity of film from fish skin gelatin incorporated with root essential oils. Journal of Food Engineering, 117, 350-360. DOI:10.1016/j.jfoodeng.2013.03.005

Tongnuanchan, P., Benjakul, S. \& Prodpran, T. (2014). Structural, morphological and thermal behavior characterizations of fish gelatin film incorporated with basil and citronella essential oils as affected by surfactants. Food Hydrocolloids, 41, 33-43. DOI:10.1016/j.foodhyd.2014.03.015

Tural, S. \& Turhan, S. (2017). Properties and antioxidant capacity of anchovy (Engraulis encrasicholus) by-product protein films containing thyme essential oil. Food Technology and Biotechnology, 55, 77-85. DOI:10.17113/ftb.55.01.17.4824

Turhan, S., Sagir, I. \& Temiz, H. (2009). Oxidative stability of brined anchovies (Engraulis encrasicholus) with plant extracts. International Journal of Food Science and Technology, 44, 386-393. DOI:10.1111/j.1365-2621.2008.01777.x

Zavareze, E.R., Halal, S.L.M., Silva, R.M., Dias, A.R.G. \& PrenticeHernandez, C. (2014). Mechanical, barrier and morphological properties of biodegradable films based on muscle and waste proteins from the Whitemouth croaker (Micropogonias furnieri). Journal of Food Processing and Preservation, 38, 1973-1981. DOI:10.1111/jfpp.12173

Zinoviadou, K.G., Koutsoumanis, K.P. \& Biliaderis, C.G. (2009). Physicochemical properties of whet protein isolate films containing oregano oil and their antimicrobial action against spoilage flora of fresh beef. Meat Science, 82, 338-345. DOI:10.1016/j.meatsci.2009.02.004 